\title{
Gc-Ms Study of Two Column Fractions from Methanol Extracts of Loranthus Micranthus and Their In Vivo Antidiabetic Activity on Alloxan Induced Diabetic Rats
}

\author{
Channabasava Govindappa $\mathbf{M}^{*}$, Chandrappa CP and Umashankar T \\ Natural Products Laboratory, Department of Biotechnology, Shridevi Institute of Engineering and Technology, India
}

\begin{abstract}
The methanol extracts of Loranthus micranthus fractions were collected from column chromatography. From TLC, the fraction 17 and 20 were selected based on the clear distiguishable of bands and few phytochemicals. Same fractions when subjected to GC-MS, fraction-17 yielded 13 and fraction-20 yielded 11 prominent compounds. Diabetic rats that were treated with the fraction 17 and 20 showed significantly increase in body weight (16.52 and $12.43 \%$ respectively). Hypoglycemic effect and antihyperlipidemic characters (decrease in the previously elevated levels of serum cholesterol and serum triglycerides) were observed. The two fractions treated rats have also showed the regeneration of pancreatic connective tissue, acini, blood vessels, blood capillaries, pancreatic ducts and their walls, islets capsule and cells in accordance to proper cytoarchitecture. The in vivo antidiabetic property may be due to the presence of single or all phytochemicals in the fraction. Greater activity was observed in fraction-17. However, further experimental studies are still needed for identification of the functionally relevant phytochemical(s) in management of diabetes in rats.
\end{abstract}

Keywords: Loranthus micranthus; In vivo; Antidiabetic; Antihyperlipidemic; GC-MS; Histopathology

\section{Introduction}

International Diabetes Federation (IDF) recent estimate indicates that $8.3 \%$ of adults -382 million people worldwide and 65.1 million people in India suffer from diabetes, and the number of people with the disease is set to rise beyond 592 million in less than the next 25 years. Yet, with 175 million of cases currently un-diagnosed, a vast number of people with diabetes are progressing unawares towards impeding complications. Moreover, with $80 \%$ of the total number affected individuals living in low- and middle-income countries, where the epidemic is gathering pace at alarming rates [1]. It may almost become a serious public health problem, particularly in developed countries as a major threat to global development $[2,3]$. This shows the necessities and the importance of more alternate and effective antidiabetic drugs and their systematic studies to manage diabetes.

Animals have been extensively used as study models to carry out diabetes research in vivo. The effect of "foreign" compounds including plant extracts on the blood constituents of an animal can be used to determine the extent of severity of the perticular disorders [4]. Flavonoids, glycosides of triterpenes, steroids and alkaloids of different plant origin showed a promising anti-diabetic activity, as demonstrated in diabetic animal models [5-7]. In animals, it can be induced by partial pancreatectomy or by the administration of diabetogenic drugs such as alloxan, streptozotocin, ditizona and anti-insulin serum. These agents selectively destroy the Langerhans islets B-cells. Alloxan and streptozotocin are widely used to induce experimental diabetes in animals. The cytotoxic action of both these diabetogenic agents is mediated by reactive oxygen species. According to the administered dose of these agents, syndromes similar to either type 1, type 2 diabetes mellitus or glucose intolerance can be induced $[8,9]$.

Loranthus micranthus is a hemiparasitic shrub commonly known as African mistletoe. It grows on woody plants for nourishment and synthesizes it's own chlorophyll. Kola acuminata, Kola nitida, Mangifera indica, Azadirachta indica, Jatropha curcas and Persia sp. were the common host plants of L. micranthus [10]. Herbals are the choice over synthetic drugs from past centuries having multiple therapeutic functions and fewer side effects. In this context it was an effort to attend towards antidibetic studies of L. micranthus in an analytical and systematic ways. L. micranthus has been widely used in ethnomedicine for various purposes, including antihypertensive, anticancer, antispasmodic, and antidiabetic, in treatment of epilepsy, headache, infertility, menopausal syndrome and rheumatism $[11,12]$ and many of medicinal activities are proven by recent researches. It decreases the blood glucose level and controls the loss of body weight in diabetes mellitus [13].

Presently the study was aimed to carry out GS-MS and in vivo antidiabetic activities of Loranthus micranthus on alloxan induced diabetic rats. Based on our earlier studies of qualitative, quantitative and some biological activities, column fractions from methanol extracts of $L$. micranthus were selected for in vivo antidiabetic studies on rats. Body weight, blood glucose level, lipid profile and histopathological changes of rats were considered in the study.

\section{Materials and Methods}

\section{Collection and processing of plant}

The fresh leaves of Loranthus micranthus growing on the host plant

*Corresponding author: Channabasava Govindappa M, Natural Products Laboratory, Department of Biotechnology, Shridevi Institute of Engineering \& Technology, Sira Road, Tumkur-572 106, Karnataka, India, Tel: +91-8162212629 (O), +91-7204238327(M), Fax: +91-8162212628; E-mail: endophytessiet@gmail.com

Received November 20, 2014; Accepted April 20, 2015; Published April 28, 2015

Citation: Channabasava Govindappa $\mathrm{M}^{*}$, Chandrappa CP, Umashankar T (2015) Gc-Ms Study of Two Column Fractions from Methanol Extracts of Loranthus Micranthus and Their In Vivo Antidiabetic Activity on Alloxan Induced Diabetic Rats. J Diabetes Metab 6: 536. doi:10.4172/2155-6156.1000536

Copyright: (c) 2015 Channabasava Govindappa M, et al. This is an open-access article distributed under the terms of the Creative Commons Attribution License, which permits unrestricted use, distribution, and reproduction in any medium, provided the original author and source are credited. 
Citation: Channabasava Govindappa M*, Chandrappa CP, Umashankar T (2015) Gc-Ms Study of Two Column Fractions from Methanol Extracts of Loranthus Micranthus and Their In Vivo Antidiabetic Activity on Alloxan Induced Diabetic Rats. J Diabetes Metab 6: 536. doi:10.4172/21556156.1000536

Page 2 of 9

Azadirachta indica were collected in the month of April, 2009 during the flowering period at DC Bungalow, Tumkur, Karnataka, India and identified using authenticated herbarium from the Department of Studies in Botany, University of Mysore, Mysore and Government Ayurvedic College, Mysore. The plant material was washed with distilled water, shade-air dried $\left(26 \pm 2^{\circ} \mathrm{C}\right)$ and pulverized to a coarse powder in a mechanical grinder, passed through a 40 mesh sieve and stored in air tight container for further work.

\section{Preparation of crude extracts}

$25 \mathrm{~g} / 100 \mathrm{ml}$ of powdered Loranthus micranthus was kept for solvent extraction in rotary shaker at $37^{\circ} \mathrm{C}, 72 \mathrm{rpm}$ for $48 \mathrm{~h}$. The methanol was used with increasing order of their polarity. The solvent extract was cetrifuged at $6000 \mathrm{rpm}$ for $10 \mathrm{~min}$ and then filtered with Whatman No. 1 filter paper and evaporated at a constant temperature of $62^{\circ} \mathrm{C}$ in hot air oven until a very concentrated extract was obtained.

\section{Column chromatography}

Column chromatography is a type of adsorption chromatography technique. Here stationary phase is a silica gel packed in a vertical column. Cotton wool was plugged at the bottom of knob to hold stationary phase to allow only the solvent and sample. Silica was activated at $110^{\otimes} \mathrm{C}$ for $20 \mathrm{~min}$ to remove moisture content. Silica slurry was prepared by starting eluent and packed sufficiently in the column. The column was eluted with an initial effluent to remove further impurities. The extract sample to be separated was placed on the top of packed stationary phase without disturbing the silica bed. The gradient elution was carried out using solvents as an increase in their polarity. The solvents used are hexane, hexane plus toluene $(2: 1,1: 1,1: 2)$, toluene, toluene plus ethyl acetate $(2: 1,1: 1,1: 2)$, ethyl acetate, ethyl acetate plus methanol $(2: 1,1: 1,1: 2)$ and methanol in different ratios. 25 eluted fractions were periodically collected at regular volumes of $5 \mathrm{ml}$ each. Repeatedly the column chomatography was carried out to reach the affordable quantity of fractions for GC-MS analysis and animal studies.

\section{GC - MS analysis}

Based upon the distinguishable phytochemical results of column chromatography and thin layer chromatography, column fractions 17 , 20 and 21 were selected for GC-MS analysis of methanolic fractions of Loranthus micranthus. GC-MS was carried out with Agilent 7890-A having an MS detector 5975-C, ionization for MS is electron impact ionization. Mass analyzer was Quadrupole. The peaks were analyzed using data analysis software NIST-2008. An experiment was carried in column HP- $5 \mathrm{~ms}$, dimensions- $30 \mathrm{~m} \mathrm{~L} \times 0.25 \mathrm{~mm}$ ID $\times 0.25 \mu \mathrm{m}$ film thickness. The initial temperature ramp was maintained at $40^{\circ} \mathrm{C}$, hold time $-2 \mathrm{~min}$. At the end the temperature ramp was $310^{\circ} \mathrm{C}$ and hold time was $10 \mathrm{~min}$. The rate of temperature ramp was $10^{\circ} \mathrm{C} / \mathrm{min}$. The experiment was programmed with total run time $34 \mathrm{~min}$, helium was used as a carrier gas at a constant flow rate of $1.0 \mathrm{ml} / \mathrm{min}$, split less flow $1 \mathrm{ml} / \mathrm{min}$. Injection volume was $1 \mu \mathrm{l}$ with scan mass range $30 \mathrm{~m} / \mathrm{z}-600$ $\mathrm{m} / \mathrm{z}$ having positive polarity (+ve).

\section{Selection of animal species}

Healthy young male albino wistar rats of 8-10 week old, weighing between $150 \mathrm{~g}$ to $200 \mathrm{~g}$ were selected for in vivo antidiabetic studies. Rats were collected from the animal house of Sree Siddaganga College of Pharmacy, Tumkur and research was carried out in Phamacology Department of Sree Siddaganga College of Pharmacy. Rats were housed in animal room at $25 \pm 2^{\circ} \mathrm{C}$ temperatures and maintained with free access to standrad food and pure water ad libitum. The animal room was regulated by a $12 \mathrm{~h}$ light and $12 \mathrm{~h}$ dark schedule.

\section{Toxicity studies $\left(\mathrm{LD}_{50}\right)$}

Based upon the results of GC-MS analysis and in vitro antidiabetic activity, column fraction-17 (CF-17) and 20 (CF-20) were selected for animal studies. Suspensions of dried, concentrated column farctions were prepared by dissolving in $0.9 \% \mathrm{v} / \mathrm{v}$ cold normal saline solution for treatment.

Toxicity studies of column fractions-17 and 20 were carried out in accordance with the modified method Lorke (1983) [14]. Maximum dose, up to $1200 \mathrm{mg} / \mathrm{kg}$ body weight was treated through oral route of administration. The animals were grouped into 6 groups involving 5 animals in each group. Group-1: $17^{\text {th }}$ fraction- $400 \mathrm{mg} / \mathrm{kg}$ body weight, Group-2: $17^{\text {th }}$ fraction- $800 \mathrm{mg} / \mathrm{kg}$ body weight, Group-3: $17^{\text {th }}$ fraction$1200 \mathrm{mg} / \mathrm{kg}$ body weight and Group- $4: 20^{\text {th }}$ fraction- $400 \mathrm{mg} / \mathrm{kg}$ body weight, Group-5: $20^{\text {th }}$ fraction- $800 \mathrm{mg} / \mathrm{kg}$ body weight, Group-6: $20^{\text {th }}$ fraction- $1200 \mathrm{mg} / \mathrm{kg}$ body weight. The rats were observed for clinical signs and symptoms of toxicity like behavioural changes and mortality within $24 \mathrm{~h}$. All the procedures were performed in accordance with the Institutional Animal Ethics Committee (IAEC). Lethal dose - $50\left(\mathrm{LD}_{50}\right)$ was then calculated as the square root of the product of the lowest lethal dose and highest non-lethal dose.

\section{Experimental induction of diabetes}

The animals were fasted for 16 - $18 \mathrm{~h}$ with free access to water prior to the administration of alloxan. Alloxan monohydrate is cyclic urea analogue have unique property of producing chronic experimental diabetes by a specific cytotoxic action on $\beta$-cells of the islets of Langerhans by a single diabetogenic dose. Diabetes was induced in nearly 70 rats by intraperitoneal (i.p.) injection of alloxan monohydrate at a dose of $120 \mathrm{mg} / \mathrm{kg}$ body weight, dissolved in $0.9 \% \mathrm{v} / \mathrm{v}$ cold normal saline solution [15]. The rats were then kept for the next $24 \mathrm{~h}$ on $5 \%$ glucose solution bottles in their cages to prevent hypoglycemia [16]. After an observational period of about $72 \mathrm{~h}$, rats with fasting plasma glucose levels above $300 \mathrm{mg} / \mathrm{dl}$ were considered diabetic.

\section{Experimental protocol}

After an observational period of $72 \mathrm{~h}$, rats with fasting plasma glucose levels above $300 \mathrm{mg} / \mathrm{dl}$ were considered as diabetic and were assigned into five groups of ten rats in each group.

Animal fasted overnight were randomly divided into 5 groups:

Group 1: NC: Normal control, treated with only normal saline $(2.0 \mathrm{ml})$ orally. Group 2: DC: Diabetic control

Group 3: STD: Diabetic rats treated with reference drug Glibenclamide, at a dose of $0.5 \mathrm{mg} / \mathrm{kg}$ body weight. Diabetic rats treated with $17^{\text {th }}$-fraction of Loranthus

Group 4: CF-17: micranthus extract, at a dose of $400 \mathrm{mg} / \mathrm{kg}$ body weight orally.

Diabetic rats treated with $20^{\text {th }}$-fraction of Loranthus

Group 5: CF-20: micranthus extract, at a dose of $400 \mathrm{mg} / \mathrm{kg}$ body weight orally.

The fasting blood glucose levels were estimated by glucose oxidaseperoxidase reactive strips (Dextrostix, Bayer Diagnostics) with Accuchek glucometer. Blood samples were collected by cutting the tip of the tail at an interval of 1,7 , and 14 days. The blood results were reported as $\mathrm{mg} / \mathrm{dl}$. Blood glucose levels were expressed in $\mathrm{mg} / \mathrm{dl}$ as mean \pm SEM. On day 14, rat's body weight, serum cholesterol and serum triglycerides were analysed. During the experiment all the rats had free access to 
Citation: Channabasava Govindappa M*, Chandrappa CP, Umashankar T (2015) Gc-Ms Study of Two Column Fractions from Methanol Extracts of Loranthus Micranthus and Their In Vivo Antidiabetic Activity on Alloxan Induced Diabetic Rats. J Diabetes Metab 6: 536. doi:10.4172/21556156.1000536

Page 3 of 9

standard rat chow and water at all times. Body weight and glycaemic change were calcuted according to the formula;

Change in body weight $(\mathrm{bw})(\%)=\left[\mathrm{bw}\right.$ on $\left(1^{\text {st }}, 7^{\text {th }}\right.$, and $14^{\text {th }}$ day) - Initial bw $\times 100] /$ Initial bw \% Glycaemic change $=$ [Glucose concentration $\left(7^{\text {th }}\right.$, and $14^{\text {th }}$ day $)-$ Fasting blood glucose $1^{\text {st }}$ day $\left.\times 100\right] /$ Fasting blood glucose.

The data were statistically analyzed using ANOVA with multiple comparisons versus control group. Values of $\mathrm{p}<0.05$ or less were taken as significant.

\section{Lipid profile}

At the end of 14 day of experimental period, blood was collected in Eppendorf tubes through retro-orbital plexus. Plasma was separated and serum was taken by centrifugation at $4^{\circ} \mathrm{C}$ using REMI-24 model centrifuge. Lipid profile viz., serum cholesterol and serum trigycerides were measured on automated analyser Olympus AU 400.

\section{Histopathology}

It is been important to study the determination of effect of two column fractions on pancreatic cytoarchitecture. At the end of $14^{\text {th }}$ day, all the animals were sacrificed by lethal chloroform vapor anaesthetia and pancreas was excised and rinsed in ice cold normal saline. A portion of the tissue was fixed in $10 \%$ formalin, cut into $5 \mu \mathrm{m}$ thick sections, and stained using hematoxylin-eosin stain and histopathological observations were made.

\section{Results}

\section{GC - MS analysis and identification of phytoconstituents}

Interpretation of GC-MS mass-spectra were carried out using the database of National Institute Standard and Technology- 2008 (NIST2008) having more than 62,000 patterns. The spectrums of the unknown components were compared with the spectrum of known components of NIST library and the parameters viz., retention time, molecular weight, structure of the components, total ionic chromatograms and ionization chromatograms were ascertained in naming the particular compound.

Three fractions of phytochemicals were analyzed by GC-MS. The literature survey indicates that some of the compounds which are present in three fractions are already exhibiting antidiabetic activity by possessing different (alternative) mechanisms and when they were isolated from other plants.

In GC-MS studies fraction-17 showed 13 detectable peaks and the compounds identified were, 1,2,3-Propanetriol diacetate, 1-Tetradecene, 2,6-bis(1,1-dimethylethyl)- 2, 5- Cyclohexadiene- 1,4dione, 2,4- bis (1,1- dimethylethyl) - Phenol, 1-\{2- [3- (2-Acetyloxiran -2- yl) -1, 1- dimethylpropyl] cycloprop -2- enyl\} ethanone, Hexadecanoic acid methyl ester, 1, 2- Benzenedicarboxylic acid butyl octyl ester, 9-Octadecenoic acid (Z) - methyl ester, Octadecanoic acid methyl ester, Eicosanoic acid methyl ester, 4,8,12,16 Tetramethylheptadecan -4- olide, 2,6,10,15,19,23-hexamethyl- (all-E)2,6,10,14,18,22-Tetracosahexaene (Squalene).

In fraction-20 there were about 11 detectable peaks and the compounds identified were, Nitrobenzene, 1-Tetradecene, 2,4-bis(1,1dimethylethyl)-Phenol, Dodecanoic acid methyl ester, Ar-tumerone (Terpene), Methyl tetradecanoate, 3,7,11,15-Tetramethyl-2hexadecen-1-ol (Phytol), Benzenepropanoic acid- 3,5-bis(1,1- dimethylethyl)-4-hydroxy- methyl ester, trans-13-Octadecenoic acid methyl ester, Methyl 16-methyl-heptadecanoate.

\section{Toxicity studies $\left(\mathrm{LD}_{50}\right)$}

Toxicity Studies of CF-17 and 20 of Loranthus micranthus were determined in rats through oral route of administration. There were no toxic features of Loranthus micranthus found in rats upto $1200 \mathrm{mg} / \mathrm{kg}$ body weight. Clinical signs and symptoms of toxicity like behavioural changes including locomotor activity and sensitivity to touch and mortality within $24 \mathrm{~h}$ and also recorded after $48 \mathrm{~h}$ after administration. Column fractions did not cause death and any abnormal behavioural changes in rats upto $1200 \mathrm{mg} / \mathrm{kg}$ body weight i.e., $100 \%$ survival rates were seen and L. micranthus was considered non toxic at such concentrations.

\section{Effect on body weight}

After the treatment of 14 day schedule it was noticed that, slight increase in the body weight of normal control rats. It may be due to their normal growth. Diabetic control rats showed $5.16 \%$ reduction in their body weight. Diabetic rats treated with standard drug Glibenclamide showed increased in the body weight by $19.03 \%$. Diabetic rats treated with Loranthus micranthus fractions were also showed significant increase in body weight by $16.52 \%$ and $12.43 \%$ for CF-17 and 20 respectively (Figure 1 and Table 1 ).

\section{Hypoglycaemic effect of column fractions of Loranthus micranthus extract}

After the 14 day treatment schedule, the result clearly indicates that, Loranthus micranthus extracts have significant hypoglycaemic effect. The decrease in blood glucose level was observed by $32.05 \%$ on $7^{\text {th }}$ day and $58.40 \%$ on $14^{\text {th }}$ day for CF-17 at $400 \mathrm{mg} / \mathrm{kg}$ body weight. For CF-20 it was observed $18.23 \%$ on $7^{\text {th }}$ day and $40.60 \%$ on $14^{\text {th }}$ day at $400 \mathrm{mg} / \mathrm{kg}$ concentration. The decreased blood glucose levels were found efficient when compared to standard drug Glibenclamide (STD) which shown blood glucose levels by $34.34 \%$ on $7^{\text {th }}$ day and $64.18 \%$ on $14^{\text {th }}$ day treatment. The increased blood glucose levels by $9.42 \%$ on $7^{\text {th }}$ and $18.20 \%$ on $14^{\text {th }}$ day were found only in diabetic control group (DC). The blood glucose on the final day of treatment were $93.43 \pm 3.86$ $\mathrm{mg} / \mathrm{dl}(\mathrm{NC}), 376.14 \pm 12.28 \mathrm{mg} / \mathrm{dl}(\mathrm{DC}), 112.04 \pm 07.15 \mathrm{mg} / \mathrm{dl}$ (STD), $133.70 \pm 11.10 \mathrm{mg} / \mathrm{dl}(\mathrm{CF}-17), 180.28 \pm 6.61 \mathrm{mg} / \mathrm{dl}$ (CF-20) (Figure 2 and Table 2).

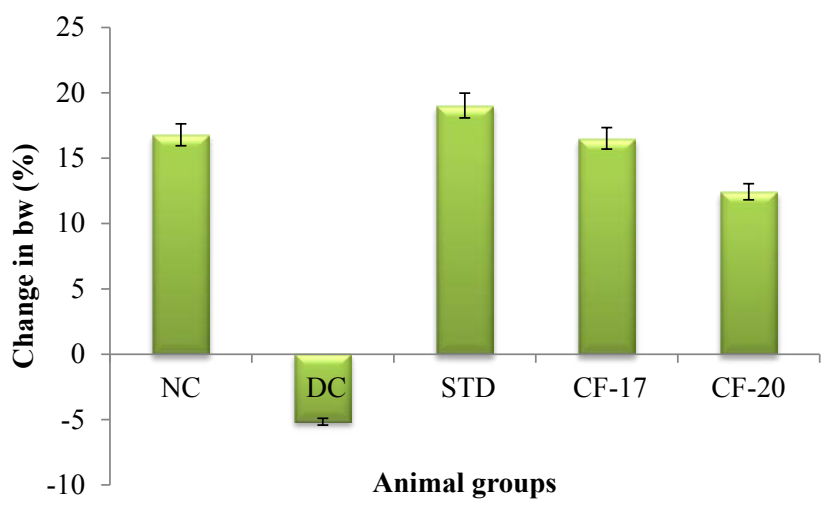

*Repeated the each experiment thrice

Figure 1: Effect of column fractions of Loranthus micranthus extract on average body weight of diabetic induced rats. 
Citation: Channabasava Govindappa M*, Chandrappa CP, Umashankar T (2015) Gc-Ms Study of Two Column Fractions from Methanol Extracts of Loranthus Micranthus and Their In Vivo Antidiabetic Activity on Alloxan Induced Diabetic Rats. J Diabetes Metab 6: 536. doi:10.4172/21556156.1000536

Page 4 of 9

\begin{tabular}{|c|c|c|c|c|c|}
\hline \multirow{2}{*}{ Group } & Dose $(\mathbf{m g} / \mathbf{k g ~ b w )}$ & \multicolumn{3}{|c|}{ Average body weight (g) } \\
\cline { 3 - 5 } & & Day 1 & \multicolumn{2}{|c|}{ Day 7 } & $210.63 \pm 5.31$ \\
\hline NC & Normal saline & $180.34 \pm 4.41$ & $196.14 \pm 3.65$ & $176.71 \pm 4.69$ \\
\hline DC & $120.0 \mathrm{mg} / \mathrm{kg} \mathrm{bw}$ & $186.34 \pm 6.52$ & $181.56 \pm 3.82$ & $218.34 \pm 5.02$ \\
\hline STD & $0.5 \mathrm{mg} / \mathrm{kg} \mathrm{bw}$ & $183.43 \pm 5.54$ & $213.13 \pm 3.61$ & -5.16 \\
\hline CF-17 & $400 \mathrm{mg} / \mathrm{kg} \mathrm{bw}$ & $175.65 \pm 4.09$ & $191.39 \pm 5.04$ & $204.67 \pm 3.19$ \\
\hline
\end{tabular}

${ }^{*}$ Repeated the each experiment thrice

Note: NC: Normal control, DC: Diabetic control, STD: Standard drug, CF-17: Column fraction-17, CF-20: Column fraction-20 and bw: Body weight

Table 1: Effect of column fractions of Loranthus micranthus extract on average body weight of diabetic induced rats.

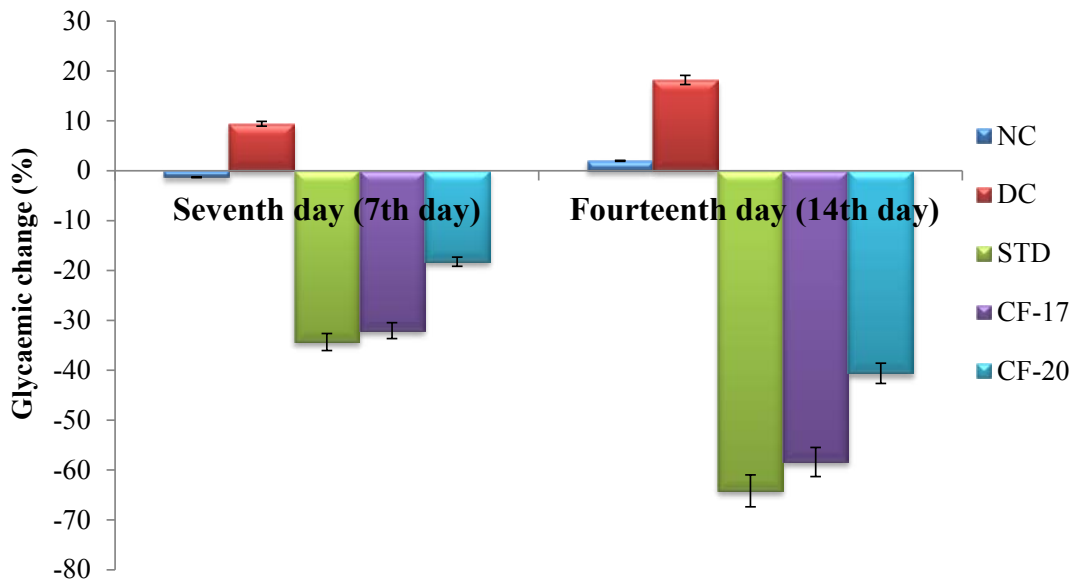

Animal groups

${ }^{*}$ Repeated the each experiment thrice

Figure 2: Effect of column fractions of Loranthus micranthus extract on blood glucose level in diabetic induced rats.

\begin{tabular}{|c|c|c|c|c|c|c|}
\hline \multirow[b]{2}{*}{ Group } & \multirow[b]{2}{*}{ Dose (mg/kg bw) } & \multicolumn{5}{|c|}{ Blood glucose concentration (mg/dl) } \\
\hline & & Day 1 & Day 7 & $\begin{array}{c}\text { Glycaemic change } \\
(\%)\end{array}$ & Day 14 & Glycaemic change (\%) \\
\hline NC & Normal saline & $91.60 \pm 4.51$ & $90.40 \pm 5.20$ & -1.31 & $93.43 \pm 3.86$ & 1.99 \\
\hline DC & $120.0 \mathrm{mg} / \mathrm{kg}$ bw & $318.20 \pm 10.50$ & $348.20 \pm 14.50$ & 9.42 & $376.14 \pm 12.28$ & 18.20 \\
\hline STD & $0.5 \mathrm{mg} / \mathrm{kg}$ bw & $312.8 \pm 12.45$ & $205.36 \pm 08.12$ & -34.34 & $112.04 \pm 07.15$ & -64.18 \\
\hline CF-17 & $400 \mathrm{mg} / \mathrm{kg} \mathrm{bw}$ & $321.40 \pm 8.50$ & $218.36 \pm 7.50$ & -32.05 & $133.70 \pm 11.10$ & -58.40 \\
\hline CF-20 & $400 \mathrm{mg} / \mathrm{kg} \mathrm{bw}$ & $303.54 \pm 11.20$ & $248.20 \pm 9.50$ & -18.23 & $180.28 \pm 6.61$ & -40.60 \\
\hline
\end{tabular}

${ }^{*}$ Repeated the each experiment thrice

Note: NC: Normal control, DC: Diabetic control, STD: Standard drug, CF-17: Column fraction-17, CF-20: Column fraction-20 and bw: Body weight

Table 2: Effect of column fractions of Loranthus micranthus extract on blood glucose level in diabetic induced rats.

\section{Effect of column fractions of Loranthus micranthus extract on serum lipid profile}

At the end of 14 day of experimental period, hyperlipidemic parameters like serum cholesterol and serum triglycerides were analyzed. The elevated levels of serum triglycerides and serum cholesterol by $132.06 \pm 0.95$ and $156.31 \pm 2.42 \mathrm{mg} / \mathrm{kg}$ bw of diabetic control group were found in comparison to the normal control. But in diabetic induced animal groups it was shown decreased levels of serum triglycerides and serum cholesterol when treated with Loranthus micranthus fractions. $98.24 \pm 1.03 \mathrm{mg} / \mathrm{kg}$ bw and $116.48 \pm 3.52 \mathrm{mg} / \mathrm{kg}$ bw for CF-17, $112.63 \pm 1.67 \mathrm{mg} / \mathrm{kg}$ bw and $131.61 \pm 2.69 \mathrm{mg} / \mathrm{kg}$ bw for CF-20 in comparison to the diabetic control group. It was noticed that, CF-17 of Loranthus micranthus showed nearly efficient activity compared to standard drug Glibenclamide $92.40 \pm 1.08$ and $105.46 \pm$ 3.02 (STD) (Figure 3 and Table 3).

\section{Histopathology}

Histopathology reports of column fractions CF-17 and CF-20 of L. micranthus on alloxan induced diabetic rats were shown significant effects. The results of all five groups were exhibited well defferentiable cytoarchitecture (Figure 4 ). The cellular changes and abnormalities of each group are mentioned below.

\section{Normal control (NC)}

There was normal distribution of islets cells, acini, blood capillaries, and pancreatic ducts were observed in normal control group. Pancreatic lobes, inter lobular duct, interlobular septa were prominent. The flow of acinar cells, blood vessels and islets of Langerhans were seems to be good in number and texture. 2-3 types of distinguishable islets cells were observed along with RBC cells. The walls of pancreatic ducts, blood vessels and Langerhans cells were organised and connected 
Citation: Channabasava Govindappa M*, Chandrappa CP, Umashankar T (2015) Gc-Ms Study of Two Column Fractions from Methanol Extracts of Loranthus Micranthus and Their In Vivo Antidiabetic Activity on Alloxan Induced Diabetic Rats. J Diabetes Metab 6: 536. doi:10.4172/21556156.1000536

Page 5 of 9

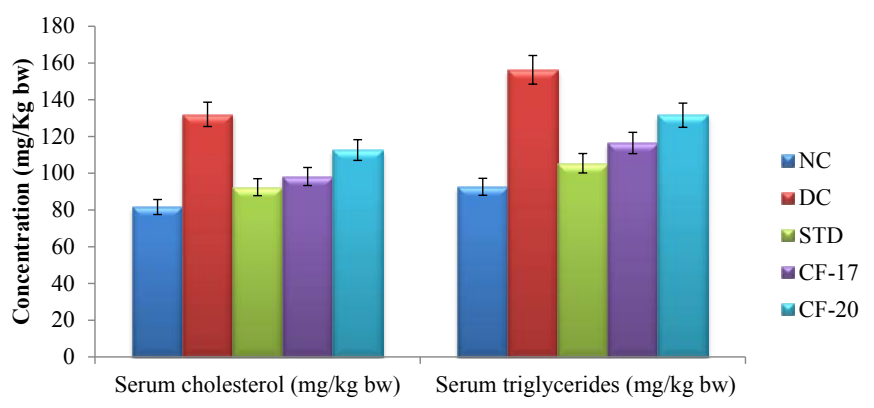

Animal groups

${ }^{*}$ Repeated the each experiment thrice

Figure 3: Effect of column fractions of Loranthus micranthus extract on serum lipid profile.

\begin{tabular}{|c|c|c|c|}
\hline Group & Dose (mg/kg bw) & $\begin{array}{c}\text { Serum cholesterol } \\
(\mathrm{mg} / \mathbf{k g ~ b w})\end{array}$ & $\begin{array}{l}\text { Serum triglycerides } \\
(\mathrm{mg} / \mathrm{kg} \mathrm{bw})\end{array}$ \\
\hline NC & Normal saline & $81.64 \pm 1.42$ & $92.61 \pm 2.62$ \\
\hline DC & $120.0 \mathrm{mg} / \mathrm{kg} \mathrm{bw}$ & $132.06 \pm 0.95$ & $156.31 \pm 2.42$ \\
\hline STD & $0.5 \mathrm{mg} / \mathrm{kg} \mathrm{bw}$ & $92.40 \pm 1.08$ & $105.46 \pm 3.02$ \\
\hline CF-17 & $400 \mathrm{mg} / \mathrm{kg} \mathrm{bw}$ & $98.24 \pm 1.03$ & $116.48 \pm 3.52$ \\
\hline CF-20 & $400 \mathrm{mg} / \mathrm{kg} \mathrm{bw}$ & $112.63 \pm 1.67$ & $131.61 \pm 2.69$ \\
\hline
\end{tabular}

*Repeated the each experiment thrice, diabetic control was compared with the normal control and extract treated groups were compared with the diabetic control. Note: NC: Normal control, DC: Diabetic control, STD: Standard drug, CF-17: Column fraction-17, CF-20: Column fraction-20 and bw: Body weight

Table 3: Effect of column fractions of Loranthus micranthus extract on serum lipid profile.

with connective tissue. Inflammatory blood vessels and inflammatory pancreatic cells were not seen (Figure 5).

\section{Diabetic control (DC)}

There were noted abnormalities in diabetic control group. Marked inflammatory blood vessels and even rupture of blood capillaries were seen. Depletion of pancreatic lobes, acini, islets of Langerhans and exocrine wall were observed. Notedly decresead number of islets of Langerhans, cells of islets and pancreatic ducts were observed. Connective tissue and blood capillaries were depleted. Some depositions on islets cells resembling amyloid formation and shrinkage of islets cells were observed. More RBC cells were interdispersed in endocrine and even in exocrine part of pancrease (Figure 6).

\section{Glibenclamide standard (STD)}

Regeneration of pancreatic ducts, acinar cells and connective cells were seen. Interlobular septa, walls of blood vessels and pancreatic ducts were seems to be normal when compared NC. Islets of Langerhans and its cells, acinar ceels, pancreatic ducts were evenly distributed. Compared to normal control the texture and numbers of pancreatic cells of glibenclamide treated animals were nearly normal (Figure 7).

\section{CF-17 of Loranthus micranthus}

Column Fraction-17 exhibited significant effects on alloxan induced diabetic rats by preventing damage of pancreatic cells by oxidative stress, since alloxan induces diabetes through oxidative stress and damage of pancreatic cells. The pancreatic connective tissue, acini, blood vessels, blood capillaries, pancreatic ducts and their walls, islets capsule, islets cells were well organised in accordance with their number, texture and dispersion in the pancreatic lobes. Islets cells were distinguished individually and noted the presence of 2-3 types of islets cells along with RBC cells. The architecture of pancreatic histology of CF-17 treated diabetic induced rats is almost similar compared to normal control group (Figure 8).

\section{CF-20 of Loranthus micranthus}

Column Fraction-20 exhibited nearly comparable results comapred to reference drug. Pancreatic architecture was normal. CF-20 exhibited prominent effects in regenration of pancreatic connective tissue, acini, blood vessels, blood capillaries, pancreatic ducts and their walls, islets capsule. Acinar cells and islets cells were well dispersed. Pancreatic tissue was organised in accordance with their number, texture. Pancreatic ducts and islets cells are evenly scattered. The sizes of islets cells seems to be normal (Figure 9).

\section{Discussion}

Out of 25 column fractions of methanolic extract, fractions 17 and 20 were chosen for GC-MS studies based on a clear separation of phytochemicals in TLC (Channabasava et al., 2014). In fraction 17,13 prominent compounds were identified and out of which 5 compounds (1,2,3-propanetriol, diacetate, Hexadecanoic acid, octadecenoic acid and eicosanoic acid) have already proved as antidiabetic activity by possessing insulin secretion, insulin stimulation, $\alpha$-glucosidase

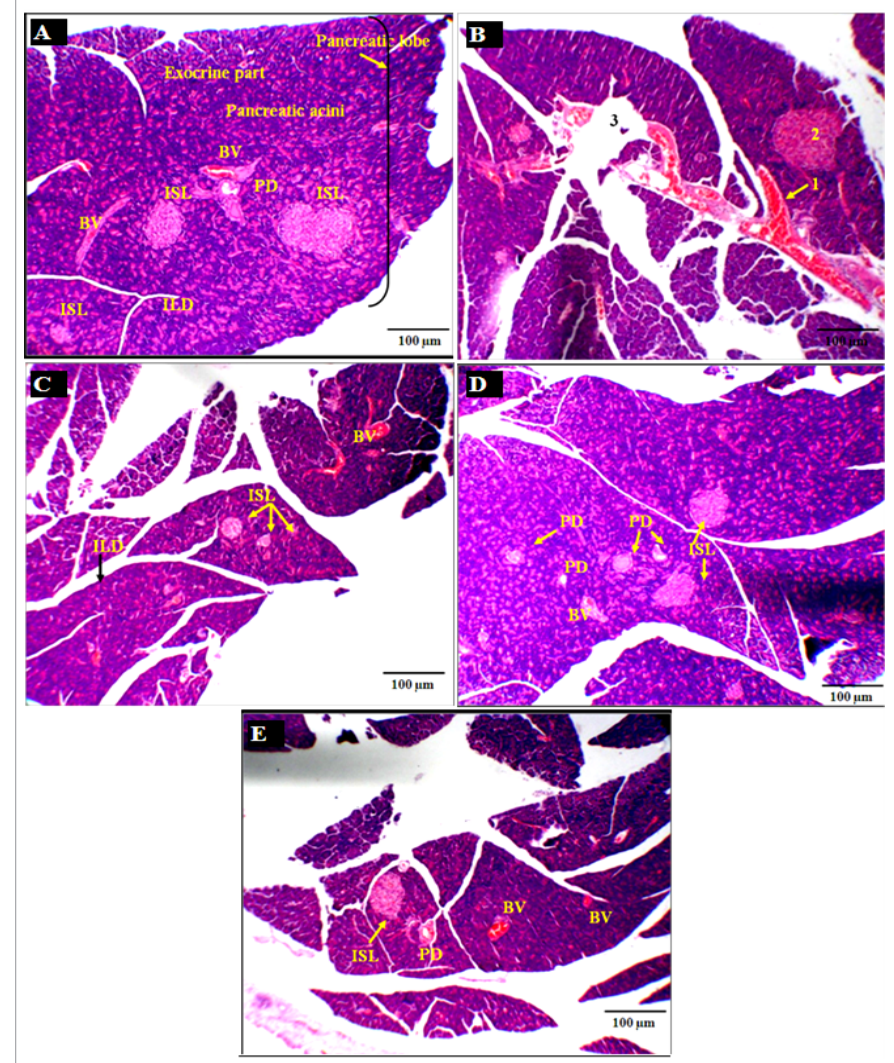

Note: BV-Blood vessel, PD-Pancreatic duct, ISL-Islets of Langerhans, ILDInterlobular duct.

Figure 4: A photomicrograph of over view of different rat pancreatic tissue, $A$ Normal control (NC), B) Diabetic control having inflammatory blood vessel, acinar and islets cell damage (DC), C) Glibenclamide, standard reference drug (STD), D) CF-17 of Loranthus micranthus extract and E) CF-20 of Loranthus micranthus extract. 
Citation: Channabasava Govindappa M*, Chandrappa CP, Umashankar T (2015) Gc-Ms Study of Two Column Fractions from Methanol Extracts of Loranthus Micranthus and Their In Vivo Antidiabetic Activity on Alloxan Induced Diabetic Rats. J Diabetes Metab 6: 536. doi:10.4172/21556156.1000536

Page 6 of 9

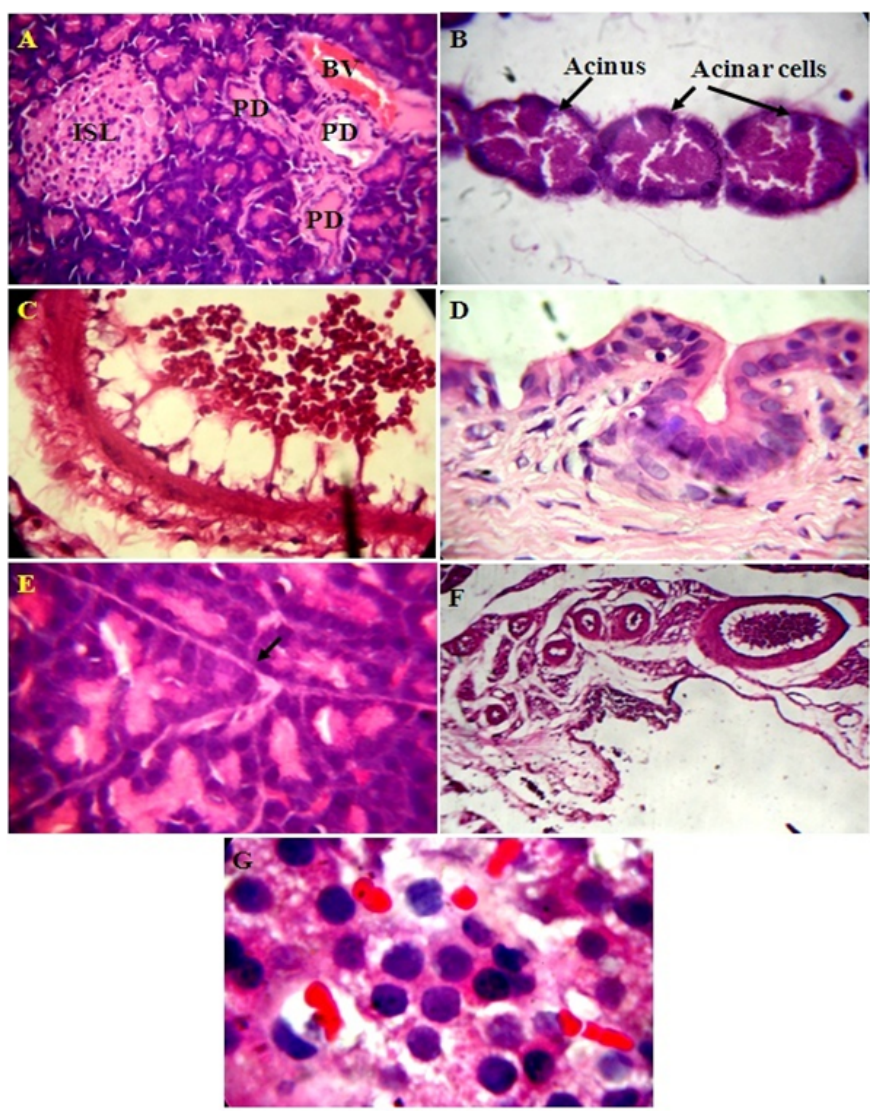

Figure 5: A photomicrograph of normal control of rat pancreatic tissue (NC), A) Normal flow of Islet's cells, blood vessel and pancreatic ducts B) Normal acini and acinar cells, C) Blood vessel having normal connective tissue and RBC cells, D) Normal exocrine pancreatic wall, E) Interlobular septa, F) More number of pancreatic dutcts and blood vessels, G) Islet's cells along with blood capillaries and RBC cells (at 100x oil immersion).

inhibitors [17-19]. Fraction 20 yielded 11 different compunds in which three compunds (ar-tumerone, 3,7,11,15-tetramethyl-2-hexadecen1-ol, trans-13-octadeceboic acid) have already exhibited antidiabetic, a-glucosidase inhibitors [20,21].

Animals are been extensively used as study model to carry out diabetes research in vivo. Similarly medicinal plant extracts also used to treat diabetes since from long ages. Column fractions CF-17 and CF-20 were selected for animal studies based upon the results exhibited by GC-MS studies and literature survey indicating the presence of different antidiabetic agents. After the treatment of 14 day schedule it was noticed that, the column fractions CF-17 and CF-20 of $L$. micranthus extract are efficient anidiabetic agents. Since diabetes mellitus is a state of multiple disorders, CF-17 and CF-20 were having the normal body weight, blood glucose level, serum lipid profile and also normal pancreatic histological charecters in alloxan induced rats.

Slight increase in the body weight of normal control rats may be due to their normal growth. But diabetic control rats showed $5.16 \%$ reduction in their body weight. Body weight is also an important determinent in diabetes mellitus. The body weight usually decreases as diabetes progresses [22]. Significant increase in the body weight by $16.52 \%$ and $12.43 \%$ for CF-17 and CF-20 of L. micranthus correlates with the work carried out by Ahmed et al. [23].

Several workers have shown the hyperglycemia and hyperlipidemia, the common characteristics of Alloxan-induced diabetes mellitus in experimental rats [24,25]. And also plant extracts have been valuable anti-diabetic agents and may involve one or more active components responsible for blood glucose reduction [26,27]. After the 14 day treatment schedule, the result clearly indicates that, CF17 and CF-20 of L. micranthus have significant hypoglycaemic effect. The antihyperglycemic results are highly correlated with the work of Harikiran et al. [28] with Bombax malabaricum and Tyagi et al. [29] with Anacyclus pyrethrum in alloxan induced rats.

Hyperlipidemia, the common characteristic of alloxan induced diabetes mellitus in experimental rats and in diabetes patients [24,25] and serum triglycerides play a role in the development and progression of renal disease in type I diabetes mellitus [30,31]. Derangements in lipid metabolism in diabetes mellitus are an important determinants and status of the disease [32]. Significant decrease in the hyperlipidemic parameters like elevated serum cholesterol and serum triglycerides by CF-17 and CF-20 of L. micranthus attributes antihyperlipidemic activity in relation to antidiabetic activity. Flavonoids isolated from different sources [33,34] and polyphenolic extracts of Ichnocarpus frutescens [35] have been documented to show antidiabetic and antihyperlipidemic activities in diabetic rats in a similar way. Thus, $L$. micranthus significe it's antidiabetic and antihyperlipidemic property and strengthen the presence of various triterpenoids, flavonoids and phenolic compounds.

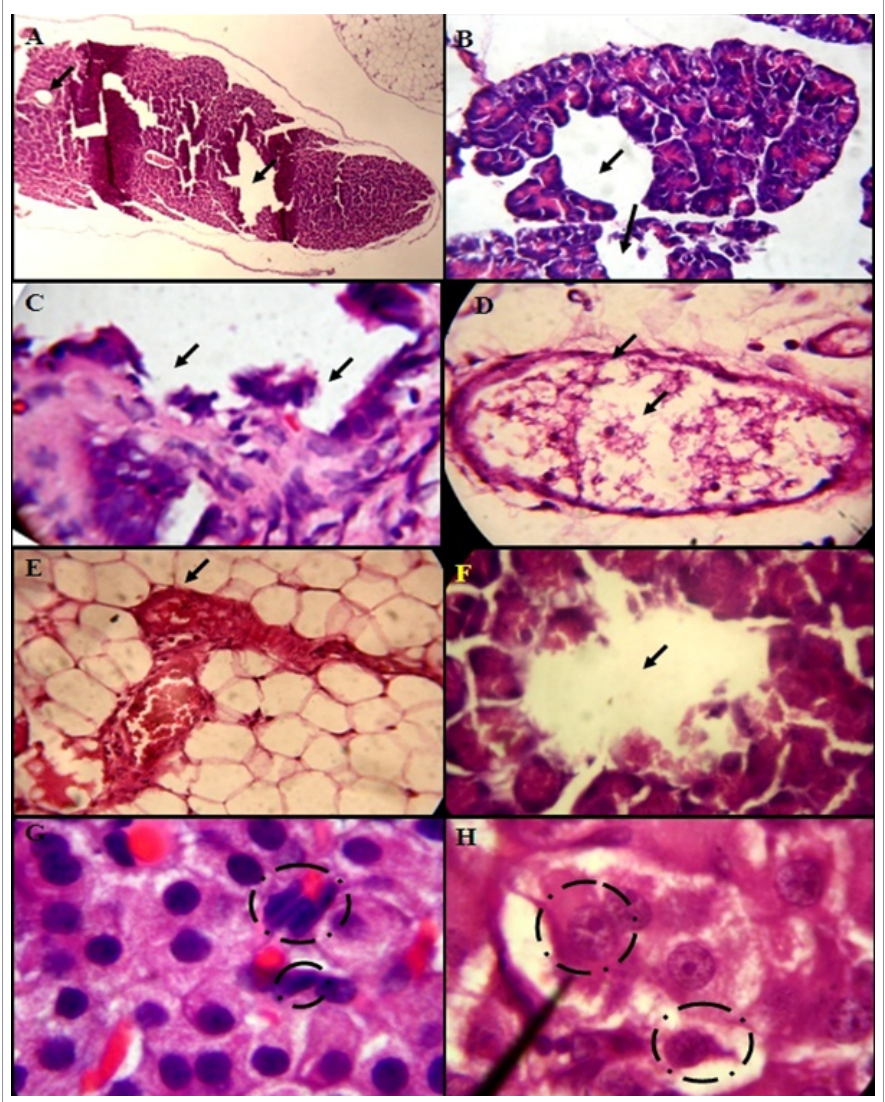

Figure 6: A photomicrograph of the effect of alloxan induction on rat pancreatic tissue in diabetic control (DC), A) Acinar cell damage and enlarged blood vessel, B) Depletion of Islet's cells, C) Depletion of exocrine layer, D) Necrosis of connective tissue of blood vessels, E) Inflammation of blood vessel, F) Islet's cells damage, G) Depletion of Islet's cells and $H$ ) Amyloid formation on Islet's cells (at 100x oil immersion). 
Citation: Channabasava Govindappa M*, Chandrappa CP, Umashankar T (2015) Gc-Ms Study of Two Column Fractions from Methanol Extracts of Loranthus Micranthus and Their In Vivo Antidiabetic Activity on Alloxan Induced Diabetic Rats. J Diabetes Metab 6: 536. doi:10.4172/21556156.1000536

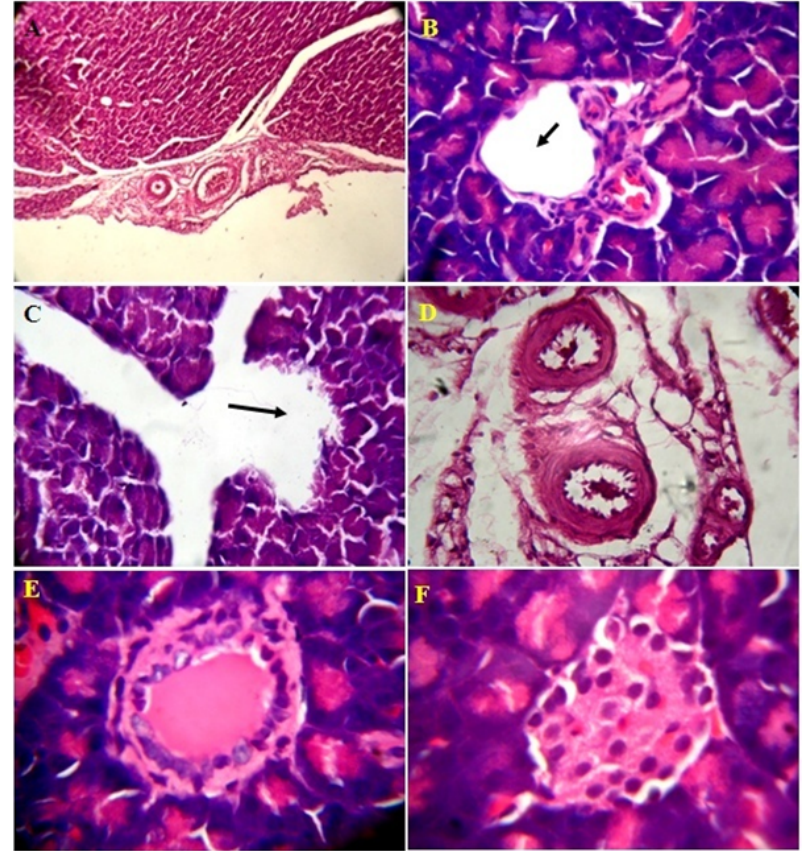

Figure 7: A photomicrograph of the effect of glibenclamide on rat pancreatic tissue (STD $=0.5 \mathrm{mg} / \mathrm{kg}$ bw), A) Blood vessel having normal connective tissue, pancreatic ducts, blood vessels, B) Recovery of Islet's cells with proper pancreatic duct and blood capillaries, C) Recovery of Islet's cells D) Increase in the number of pancreatic ducts and proper connective tissue $\mathrm{E}$ ) Normal pancreatic duct and F) Normal acini with Islet's cells and RBC cells (at 100x oil immersion).

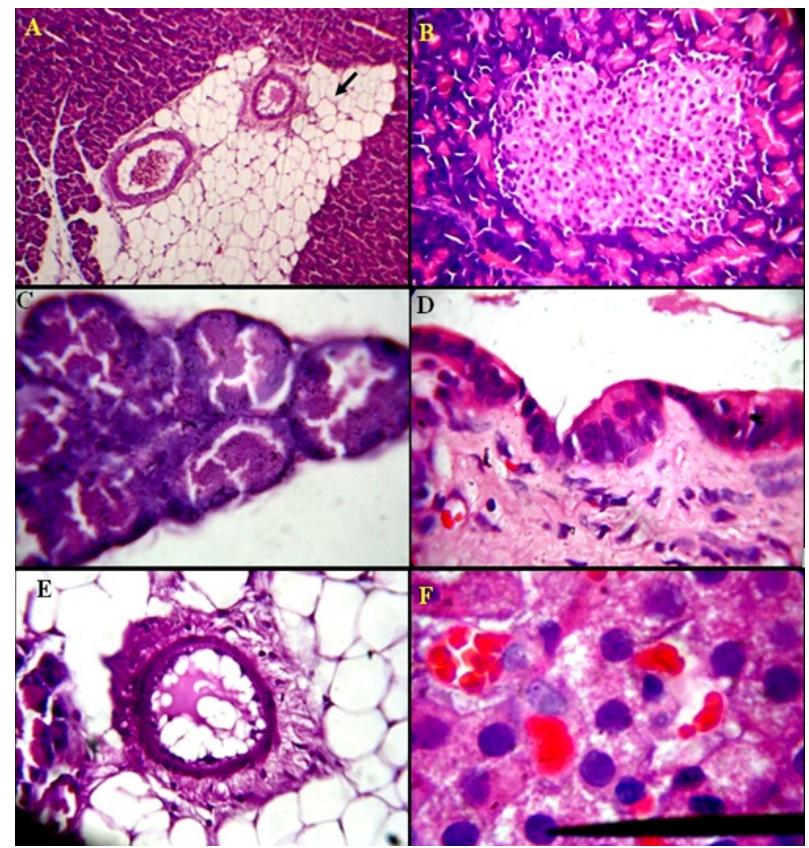

Figure 8: A photomicrograph of the effect of CF-17 of Loranthus micranthus extract on rat pancreatic tissue, A) Normal flow of connective tissue and proper blood vessels with exocrine part of pancreas, B) Prominent Islet's cells in Islets of Langerhans, C) Normal acini with proper adherence, D) Prominent exocrine pancreatic wall, E) Normal pancreatic duct having proper connective tissue and F) Distinguishable Islet's cells along with blood capillaries and RBC cells (at 100x oil immersion).

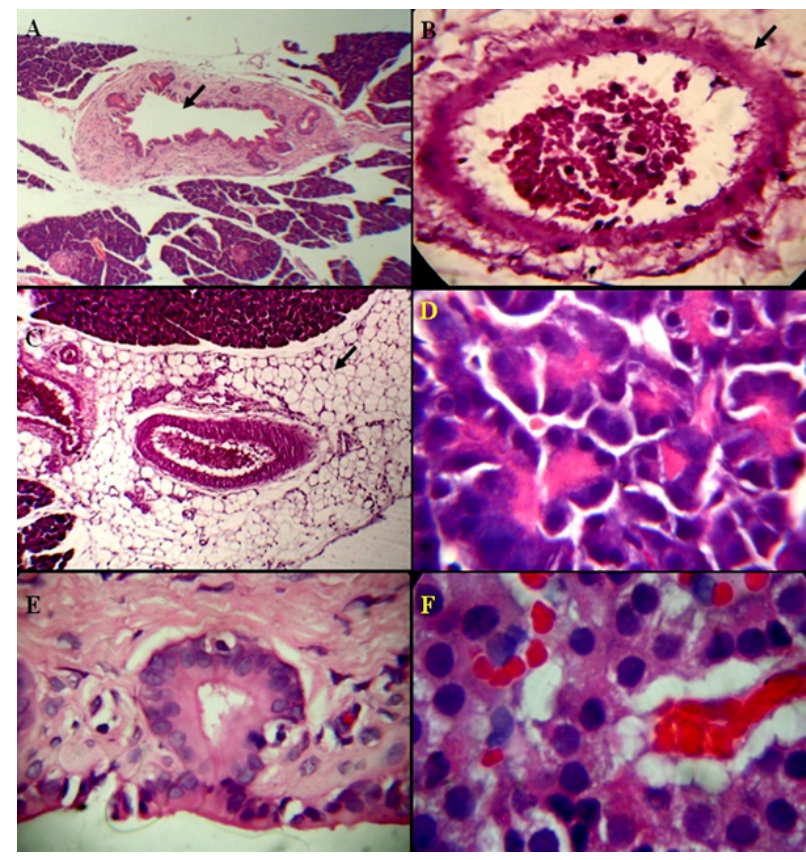

Figure 9: A photomicrograph of the effect of CF-20 of Loranthus micranthus extract on rat pancreatic tissue, A) Normal flow of connective tissue between exocrine part of pancreatic lobes, B) Blood vessel having normal connective tissue and RBC cells, C) Normal pancreatic ducts, blood vessels of exocrine pancreas D) Normal acini with acinar cells, E) Normal exocrine pancreatic wall, F) Islet's cells along with blood capillaries and RBC cells (at 100x oil immersion).

Alloxan is a hydrophilic and unstable analogue of glucose and selectively destroys beta cells of islets of pancreas, results in the elevation of blood glucose level, decreases protein content, and increases levels of cholesterol and triglycerides [36]. Alloxan and its product dialuric acid establish a redox potential and forms superoxide radicals. These reactive oxygen species with a simultaneous massive increase in cytosolic calcium concentration causes rapid destruction of B-cells [37]. Decreasing the islets cell numbers, cell damage, and cell death [38], thickened and hyalinized blood vessels causing hypoxia and resulting in degenerative changes and necrosis [39] and structural and functional alterations such as disorganization of pancreatic architecture and depletion of insulin producing cells [40-42] are the significant pancreatic histological changes observed in alloxan induction. Histopathology reports of CF-17 and CF-20 of L. micranthus have shown clear confirmative results of regeneration of pancreatic connective tissue, acini, blood vessels, blood capillaries, pancreatic ducts and their walls, islets capsule, islets cells in accordance with their organization, number, texture and dispersion in the pancreatic lobes. The results were correlated with the work carried out by Prince and Kamalakkannan (2006) [43] reported the beneficial effects of rutin on islet morphology, oxidative status and glycemia in diabetic rats. The general mechanisms of regeneration include replication of existing mature $\beta$-cells and differentiation or neogenesis by ductal or intra-islet pancreatic precursor cells [44]. In alloxan-induced diabetes, (-)-epicatechin [45] and Vinca rosea extract [46] have also shown to act by $\beta$-cell regeneration and decrease in blood glucose.

\section{Conclusion}

The present histological study strongly provides evidance that the two fractions exert protective effect in Alloxan induced diabetic rats. 
Citation: Channabasava Govindappa M*, Chandrappa CP, Umashankar T (2015) Gc-Ms Study of Two Column Fractions from Methanol Extracts of Loranthus Micranthus and Their In Vivo Antidiabetic Activity on Alloxan Induced Diabetic Rats. J Diabetes Metab 6: 536. doi:10.4172/21556156.1000536

Hence, it is concluded that the two fractions possess preventive and useful effect. And it can be used as herbal medicine to protect islet cells or manage diabetes.

\section{Acknowledgement}

We thank Dr MR Hulinaykar, Managing Trustee, Sri Shridevi Charitable Trust (R.) and Dr Shashidhara SM, Principal, SIET, Tumkur, India for encouragement and suggestions during the research. We also thank, Dr Prasad S Koka is a Ramalingaswami Fellow of the Depertment of Biotechnology, Government of India, New Delhi.

\section{References}

1. Patterson C, Guariguata L, Dahlquist G3, Soltész G4, Ogle G5, et al. (2014) Diabetes in the young - a global view and worldwide estimates of numbers of children with type 1 diabetes. Diabetes Res Clin Pract 103: 161-175.

2. Vessby B (2000) Dietary fat and insulin action in humans. Br J Nutr 83 Supp 1: S91-96.

3. Seidell JC (2000) Obesity, insulin resistance and diabetes--a worldwide epidemic. Br J Nutr 83 Suppl 1: S5-8.

4. Yakubu MT, Akanji MA, Oladiji AT (2007) Haematological evaluation in male albino rats following chronic administration of aqueous extract of Fadogia agrestis stem. Pharmacol Manage 3: 34-38.

5. Nojima H, Kimura I, Chen FJ, Sugihara Y, Haruno M, et al. (1998) Antihyperglycemic effects of $\mathrm{N}$-containing sugars from Xanthocercis zambesiaca, Morus bombycis, Aglaonema treubii, and Castanospermum australe in streptozotocin-diabetic mice. J Nat Prod 61: 397-400

6. Kim HY, Moon BH, Lee HJ, Choi DH (2004) Flavonol glycosides from the leaves of Eucommia ulmoides $\mathrm{O}$. with glycation inhibitory activity. J Ethnopharmacol 93: $227-230$.

7. Kako M, Miura T, Nishiyama Y, Ichimaru M, Moriyasu M, et al. (1997) Hypoglycemic activity of some triterpenoid glycosides. J Nat Prod 60: 604-605

8. Lenzen S, Tiedge M, Jorns A, Munday R (1996) Alloxan derivatives as a too for the elucidation of the mechanism of the diabetogenic action of alloxan. In: Lessons from Animal Diabetes. Birkhauser, Boston 113-122.

9. Mythili MD, Vyas R, Akila G, Gunasekaran S (2004) Effect of streptozotocin on the ultrastructure of rat pancreatic islets. Microsc Res Tech 63: 274-281.

10. Osadebe PO, Ukweze SE (2004) A comparative study of the phytochemical and antimicrobial properties of the Eastern Nigerian species of African mistletoe (Loranthus micranthus) sourced from different host areas trees. Journal of Biological Research and Biotechnology 2:18-23.

11. Nwude N, Ibrahim MA (1980) Plants used in traditional veterinary medica practice in Nigeria. Journal of veterinary pharmacology and therapeutics 3 : 261-273.

12. Kafaru E (1993) Mistletoe-an example of an all-purpose herb- herbal remedies. Guardian newspaper 3: 11

13. Obatomi DK, Bikomo EO, Temple VJ (1994) Anti-diabetic properties of the African mistletoe in streptozotocin-induced diabetic rats. J Ethnopharmacol 43 13-17.

14. Lorke D (1983) A new approach to practical acute toxicity testing. Arch Toxico 54: $275-287$

15. Katsumata K, Katsumata Y, Ozawa T, Katsumata K Jr (1993) Potentiating effects of combined usage of three sulfonylurea drugs on the occurrence of alloxan diabetes in rats. Horm Metab Res 25: 125-126.

16. Dhandapani S, Subramanian VR, Rajagopal S, Namasivayam N (2002) Hypolipidemic effect of Cuminum cyminum L. on alloxan-induced diabetic rats. Pharmacol Res 46: 251-255.

17. Wuttke A, Idevall-Hagren O, Tengholm A (2013) P2Y1 receptor-dependent diacylglycerol signaling microdomains in $B$ cells promote insulin secretion. FASEB J 27: 1610-1620.

18. Parker SM, Moore PC, Johnson LM, Poitout V (2003) Palmitate potentiation of glucose-induced insulin release: a study using 2-bromopalmitate. Metabolism 52: $1367-1371$

19. Balogun OS, Oladosu IA, Akinnusi A, Zhiqiang L (2013) Fatty acids composition, a-glucosidase inhibitory potential and cytotoxicity activity of Oncoba spinosa Forssk. Elixir Appl. Chem 59: 15637-15641.
20. Elmazar MM, El-Abhar HS, Schaalan MF, Farag NA (2013) Phytol/Phytanic acid and insulin resistance: potential role of phytanic acid proven by docking simulation and modulation of biochemical alterations. PLoS One 8: e45638.

21. Artanti N, Tachibana S, Kardono LB, Sukiman H (2012) Isolation of alphaglucosidase inhibitors produced by an endophytic fungus, Colletotrichum $\mathrm{sp}$. TSC13 from Taxus sumatrana. Pak J Biol Sci 15: 673-679.

22. Kamanna VS, Roh DD, Kirschenbaum MA (1998) Hyperlipidemia and kidney disease: concepts derived from histopathology and cell biology of the glomerulus. Histol Histopathol 13: 169-179.

23. Ahmed MF, Kazim SM, Ghori SS, Mehjabeen SS, Ahmed SR, et al. (2010) Antidiabetic Activity of Vinca rosea extracts in alloxan-induced diabetic rats. International Journal of Endocrinology 6.

24. Saravanan G, Pari L (2003) Effect of Cogent db, a herbal drug, on serum and tissue lipid metabolism in experimental hyperglycaemic rats. Diabetes Obes Metab 5: 156-162.

25. Luo Q, Cai Y, Yan J, Sun M, Corke H (2004) Hypoglycemic and hypolipidemic effects and antioxidant activity of fruit extracts from Lycium barbarum. Life Sci 76: $137-149$

26. Marles RJ, Farnsworth NR (1995) Antidiabetic plants and their active constituents. Phytomedicine 2: 137-189.

27. Grover JK, Yadav S, Vats V (2002) Medicinal plants of India with anti-diabetic potential. J Ethnopharmacol 81: 81-100

28. Harikiran L, Swapna CH, Someshwar K, Rama G, Krishna K, et al. (2011) Antihyperglycemic effects of Bombax malabaricum extracts in alloxan-induced diabetic rats, Pelagia Research Library. Der Pharmacia Sinica 2: 74-80.

29. Tyagi S, Mansoori MD, Singh NK, Shivhare MK, Bhardwaj P, et al. (2011) Antidiabetic effect of Anacyclus pyrethrum DC in alloxan induced diabetic rats. European Journal of Biological Sciences 3: 117-120.

30. Baquer NZ, Gupta D, Raju J (1998) Regulation of metabolic pathways in live and kidney during experimental diabetes: Effects of antidiabetic compounds. Indian J Clin Biochem 13: 63-80.

31. Hadjadj S, Duly-Bouhanick B, Bekherraz A, Brldoux F, Gallois Y, et al. (2004) Serum triglycerides are a predictive factor for the development and the progression of renal and retinal complications in patients with type 1 diabetes. Diabetes Metab 30: 43-51.

32. Bach JF (1997) Autoimmunity and type I diabetes. Trends Endocrinol Metab 8: $71-74$.

33. Vessal M, Hemmati M, Vasei M (2003) Antidiabetic effects of quercetin in streptozocin-induced diabetic rats. Comp Biochem Physiol C Toxicol Pharmacol 135C: 357-364.

34. Fuhrman B, Aviram M (2001) Flavonoids protect LDL from oxidation and attenuate atherosclerosis. Curr Opin Lipidol 12: 41-48.

35. Kumarappan CT, Rao TN, Mandal SC (2007) Polyphenolic extract of Ichnocarpus frutescens modifies hyperlipidemia status in diabetic rats. Journal of Cell and Molecular Biology 6: 175-187.

36. Dhanabal SP, Raja MK, Ramanathan M, Suresh B (2007) Hypoglycemic activity of Nymphaea stellata leaves ethanolic extract in alloxan induced diabetic rats. Fitoterapia 78: 288-291.

37. Szkudelski T (2001) The mechanism of alloxan and streptozotocin action in B cells of the rat pancreas. Physiol Res 50: 537-546.

38. Dahech I, Belghith KS, Hamden K, Feki A, Belghith H, et al. (2011) Oral administration of levan polysaccharide reduces the alloxan-induced oxidative stress in rats. Int J Biol Macromol 49: 942-947.

39. Pushparaj P, Tan CH, Tan BK (2000) Effects of Averrhoa bilimbi leaf extract on blood glucose and lipids in streptozotocin-diabetic rats. J Ethnopharmacol 72: 69-76.

40. Davidson PM, Campbell IL, Oxbrow L, Hutson JM, Harrison LC (1989) Pancreatic beta cell proliferation in rabbits demonstrated by bromodeoxyuridine labeling. Pancreas 4: 594-600.

41. Waguri M, Yamamoto K, Miyagawa J, Tochino Y, Yamamori K, et al. (1997) Demonstration of two different processes of $ß$-cell regeneration in a new diabetic mouse model induced by selective perfusion of alloxan. Diabetes 46 : 1281-1290. 
Citation: Channabasava Govindappa $\mathrm{M}^{*}$, Chandrappa CP, Umashankar T (2015) Gc-Ms Study of Two Column Fractions from Methanol Extracts of Loranthus Micranthus and Their In Vivo Antidiabetic Activity on Alloxan Induced Diabetic Rats. J Diabetes Metab 6: 536. doi:10.4172/21556156.1000536

Page 9 of 9

42. Hashemi M, Dostar Y, Rohani SR, AziziSaraji AR, Bayat M (2009) Influence of aloxanes on the apoptosis of pancreas ß-cells of rat. World J Med Sci 4: 70-73.

43. Stanley Mainzen Prince P, Kamalakkannan N (2006) Rutin improves glucose homeostasis in streptozotocin diabetic tissues by altering glycolytic and gluconeogenic enzymes. J Biochem Mol Toxicol 20: 96-102.

44. Banerjee M, Kanitkar M, Bhonde RR (2005) Approaches towards endogenous pancreatic regeneration. Rev Diabet Stud 2: 165-176.
45. Chakravarthy BK, Gupta S, Gode KD (1982) Functional beta cell regeneration in the islets of pancreas in alloxan induced diabetic rats by (-)-epicatechin. Life Sci 31: 2693-2697.

46. Ghosh S, Suryawanshi SA (2001) Effect of Vinca rosea extracts in treatment of alloxan diabetes in male albino rats. Indian J Exp Biol 39: 748-759. 